\title{
Hyperthyroidism Due to Papillary Thyroid Carcinoma Associated with Ductal Breast Carcinoma
}

\author{
Maria de Fátima Borges*, Ilka Mara Borges Botelho Modolo, \\ Rodrigo Gimenez Pissutti Modolo, Lilian Carla Silva, Luciene Mayumi Sato, \\ Rogério Costa Tiveron, Delcio Scandiuzzi, Marcus Aurelho Lima \\ Discipline of Endocrinology, Federal University of Triângulo Mineiro, Uberaba, Brazil \\ Email: borgmf@uol.com.br, rodrigo modolo@yahoo.com.br, liliancarlasilva@yahoo.com.br, \\ luciene.sato@gmail.com, rogeriotiveron@yahoo.com.br, delcio@mednet.com.br, lima@mednet.com.br
}

Received 11 June 2014; revised 12 July 2014; accepted 13 August 2014

Copyright @ 2014 by authors and Scientific Research Publishing Inc.

This work is licensed under the Creative Commons Attribution International License (CC BY). http://creativecommons.org/licenses/by/4.0/

(c) (i) Open Access

\section{Abstract}

Thyroid tumors are usually associated with euthyroidism, and hyper functioning tumors are rare. There are few reports of carcinomas associated with hyperthyroidism. The aim of this study is to describe a case of hyper functioning papillary carcinoma associated with breast carcinoma. We present a 46-year-old woman that was referred for investigation of thyroid and breast nodules detected by routine ultrasound. She presented with hyperthyroidism and enlarged left thyroid lobe with fibroelastic consistency. Investigation demonstrated papillary carcinoma with follicular hyperactivity and invasive ductal carcinoma of the breast. The patient developed metastases 6 months later and died. This study demonstrates that hot thyroid nodules may harbor malignant tumors and should be punctured. The association with breast adenocarcinoma and the unfavorable outcome suggest higher aggressiveness of this tumor in the presence of hyperthyroidism.

\section{Keywords}

Papillary Carcinoma, Hyperthyroidism, Breast Carcinoma, Thyroid, Metastasis

\section{Introduction}

The association between hyperthyroidism and thyroid carcinoma, although rare, has been systematically reported over the last 60 years, first as isolated cases [1]-[3], later in large series of patients submitted to thyroi-

${ }^{*}$ Corresponding author.

How to cite this paper: de Fátima Borges, M., Modolo, I.M.B.B., Modolo, R.G.P., Silva, L.C., Sato, L.M., Tiveron, R.C., Scandiuzzi, D. and Lima, M.A. (2014) Hyperthyroidism Due to Papillary Thyroid Carcinoma Associated with Ductal Breast Carcinoma. Case Reports in Clinical Medicine, 3, 479-486. http://dx.doi.org/10.4236/crcm.2014.38105 
dectomy due to thyroid cancer [4]-[6] or in the ones with hyperthyroidism, in which, thyroid cancer was considered an unexpected finding [7] [8]. The first studies reported the association of hyperthyroidism with metastatic follicular tumors [2] [3] and toxic adenomas [1] and, subsequently, with Graves' disease and toxic multinodular goiter [6]. They suggested that hyperthyroidism could no longer be considered an indicator of benign thyroid disease and requires careful evaluation.

Differentiated thyroid carcinoma is usually associated with euthyroidism and may coexist with thyrotoxicosis if it occurs simultaneously with Graves' disease, or even with autonomous toxic carcinoma. If thyrotoxicosis is due to the tumor cell mass, demonstrated in most cases by clinical-histopathological correlation, toxic thyroid carcinoma is diagnosed as reported in the literature [9] [10].

Most malignant thyroid tumors associated with hyperthyroidism so far reported, are papillary microcarcinomas $(<1 \mathrm{~cm})$, and had shown a favorable outcome after surgical treatment [5] [6].

The aim of the present study was to report a rare case of toxic papillary thyroid carcinoma, i.e., the tumor itself showed histological signs of hyperactivity suggesting increased thyroid hormone secretion, resulting in the clinical presentation of hyperthyroidism. In addition, invasive ductal carcinoma of the breast showing an aggressive behavior was present concomitantly, resulting in an association that has generated much literature controversy [11] [12].

\section{Patient}

A 46-year-old housewife, born and living in Uberaba, Minas Gerais, Brazil, was referred by her gynecologist on February 6, 2008, for investigation of a thyroid nodule detected by routine examination. A breast nodule was detected simultaneously by ultrasound and the patient was investigated for the two diseases.

A directed interview was performed and the patient reported profuse sweating, excessive heat, chronic fatigue, emotional lability and weight loss of $10 \mathrm{~kg}$ over the last year. The last symptom was attributed to epigastralgia and gastritis causing reduced food intake. The patient also reported frequent episodes of migraine. She had no family history of breast or thyroid cancer.

Upon physical examination, the patient weighted $69 \mathrm{~kg}$, measured $1.67 \mathrm{~m}$, and had a body mass index (BMI) of $24.8 \mathrm{~kg} / \mathrm{m}^{2}$. The patient was in good general condition, had normal skin color, was well-hydrated, and anicteric. Examination revealed a painless and movable enlarged left thyroid lobe of fibroelastic consistency, but without delimitation of the nodule. The right lobe presented a normal volume and no nodules. Heart: rhythmic, normophonetic, without murmurs at $88 \mathrm{spm}$. The lungs were clean and no visceromegalies were detected in the abdomen. The patient presented discrete edema of the lower limbs.

\section{Laboratory Tests}

Laboratory tests revealed reduced TSH $(0.005 \mu \mathrm{IU} / \mathrm{ml}$; reference value (RV): 0.38 - 4.5) and increased free T4 (4.26 ng/dl; RV: 0.8 - 2.3); anti-TPO: < $10 \mathrm{IU} / \mathrm{ml}$ (RV: < 10); anti-TG: < $20 \mathrm{IU} / \mathrm{ml}$ (RV: < 20). Ultrasonography revealed a heterogenous echotexture of the left thyroid lobe and an isoechoic nodule measuring $1.5 \times 0.9 \times 1.1$ $\mathrm{cm}$ in the middle third. Scintigraphy of the thyroid showed a topic gland, a hot nodule in the left lobe and suppressed contralateral lobe (uptake: 5.2\%; RV: $1 \%$ to $4 \%$ ) (Figure 1).

In view of the personal history of the patient, ultrasound-guided fine needle aspiration biopsy (FNAB) of the thyroid was performed, which demonstrated papillary carcinoma with cystic alterations and indirect signs of follicular hyperactivity characterized by high cells plenty of reabsortion vacuoles, colloid cytoplasmic granules and cariomegaly (Figure 2).

The patient received $40 \mathrm{mg} /$ day methimazole for compensation of hyperthyroidism prior to thyroid and breast surgery. After 2 months of clinical treatment, the patient was submitted to quadrantectomy of the left breast and total thyroidectomy, which were performed during the same surgical procedure

The thyroid weighed $37.1 \mathrm{~g}$, measured $6.0 \times 5.5 \times 3.5 \mathrm{~cm}$ in the longitudinal, lateral and anteroposterior direction respectively. The external surface was bosselated and presented a bright reddish-brown color, with evident vascularization. The cut surface (Figure 3) showed an unencapsulated, bright pinkish-grey nodule with ill-defined margins located in the middle third of the left lobe $0.7 \mathrm{~cm}$ from the subscapular region. The nodule measured $2.2 \times 1.2 \times 0.7 \mathrm{~cm}$, had an elastic consistency, and scar-like appearance. The nodule was surrounded by elastic, bright red wine-colored tissue, contrasting with the remaining thyroid parenchyma which presented a light brown color. Five elastic, yellowish-brown lymph nodes measuring 0.3 to $0.8 \mathrm{~cm}$ were identified on the 


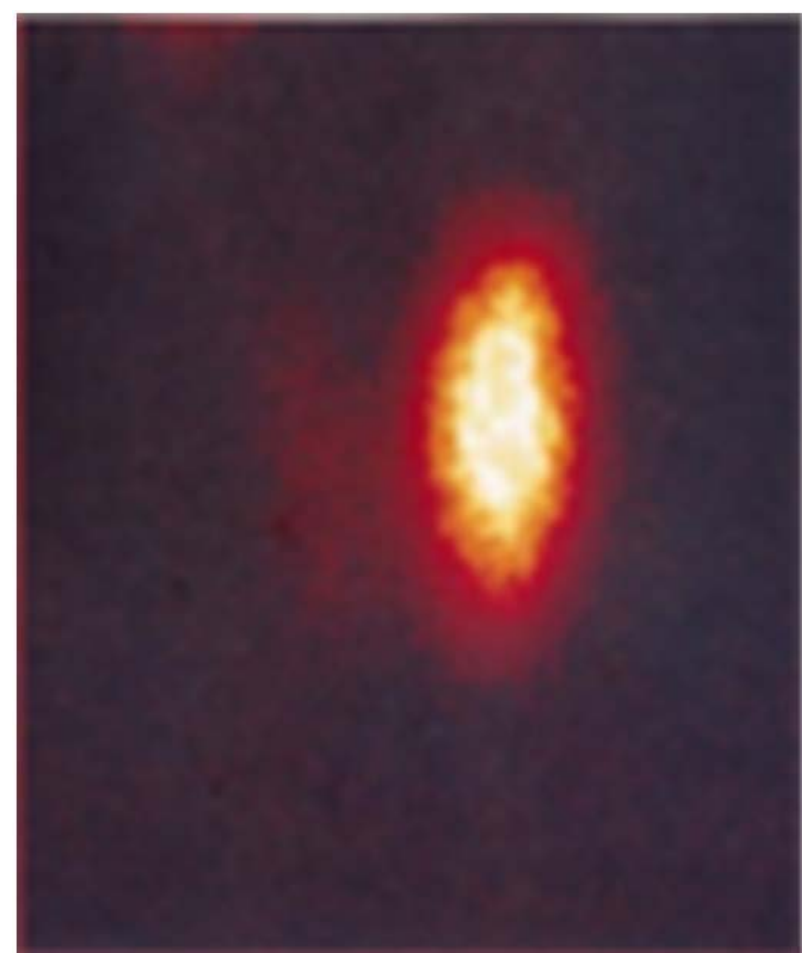

Figure 1. Pertechnetate scintigraphy of the thyroid showing a hot nodule and the remaining suppressed gland.

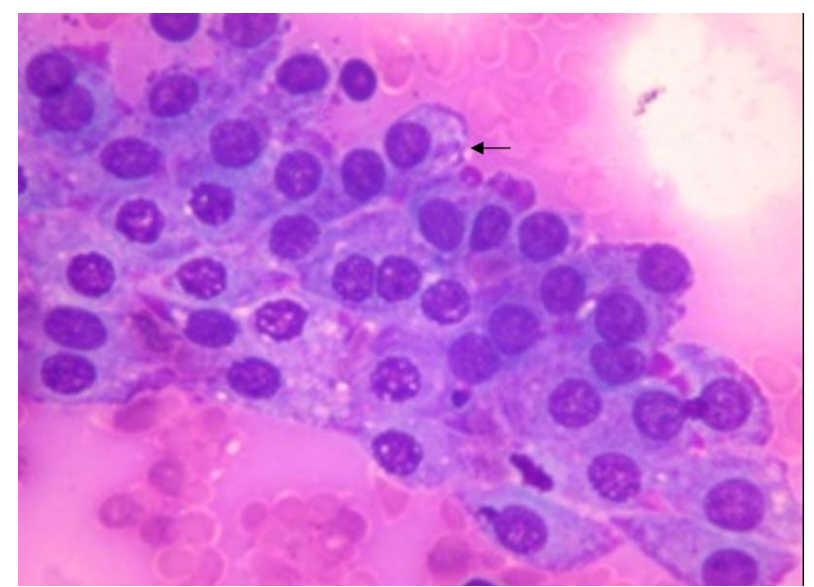

Figure 2. Group of carcinoma cells with finely granular cytoplasm and marginal cytoplasmic vacuoles ("flore cells"), signs of hyperactivity (Romanovsky stain, 200×).

posterior surface of the thyroid.

The diagnosis was papillary carcinoma located in the middle third of the left lobe and measuring $2.2 \mathrm{~cm}$ (Figure 4), without vascular or thyroid capsule invasion. The thyroid parenchyma surrounding, as well as the tumor itself, presented follicular hyperactivity, whereas no alterations were observed in the remaining parenchyma, indicating a toxic carcinoma (Figure 5). Five lymph nodes were present, two of them with papillary carcinoma metastases measuring $2 \mathrm{~mm}$ in diameter and without extranodal extension. Due to these findings, the pathological tumor stage was pT2 pN1a pMx.

Anatomopathological examination of the breast revealed a brownish-grey, hard, oval-shaped nodule with illdefined margins in the retroareolar region, measuring $1.6 \times 0.7 \times 0.7 \mathrm{~cm}$ and radiating to the periphery (Figure 6). 


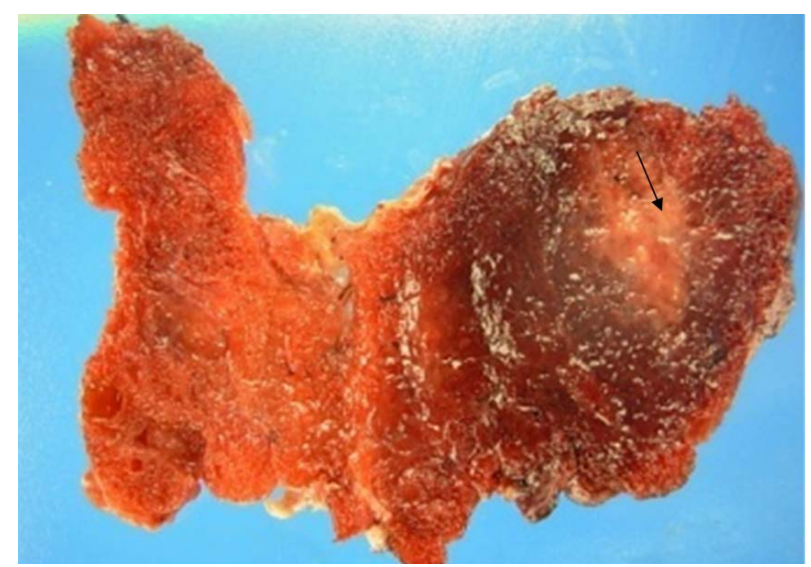

Figure 3. Cut surface of the thyroid with a nodule in the middle third of the left lobe measuring $2.2 \times 1.2 \times 0.7 \mathrm{~cm}$ surrounded by bright red wine-colored tissue, contrasting with the remaining paler thyroid parenchyma.

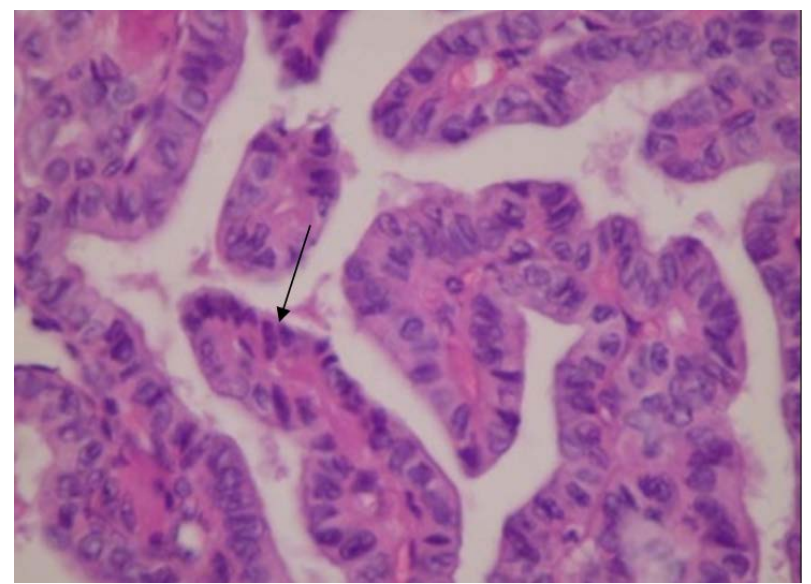

Figure 4. Papillary carcinoma showing papillae lined with cells containing irregular nuclei with clefts and, sometimes, pseudoinclusions (HE, 400×).

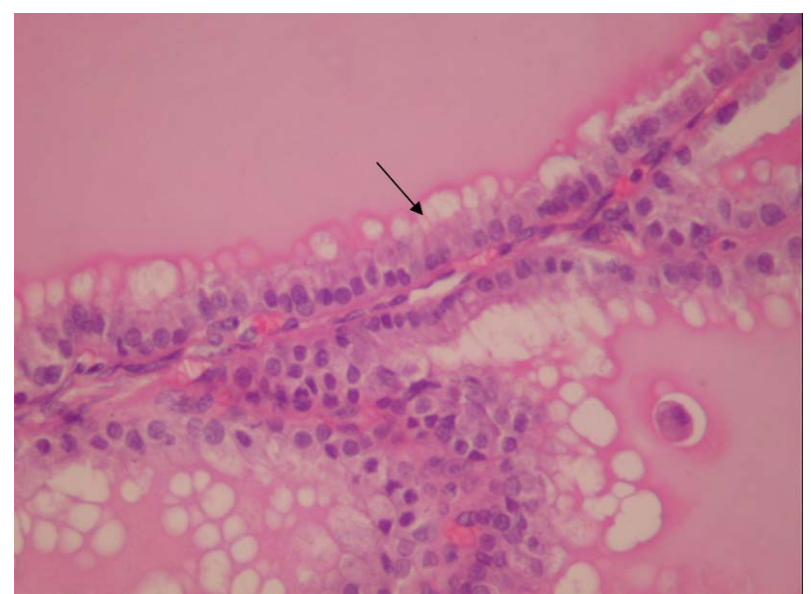

Figure 5. The thyroid carcinoma shows enlarged cells with marginal cytoplasmic vacuoles, signs of follicular hyperactivity (HE, 200×). 


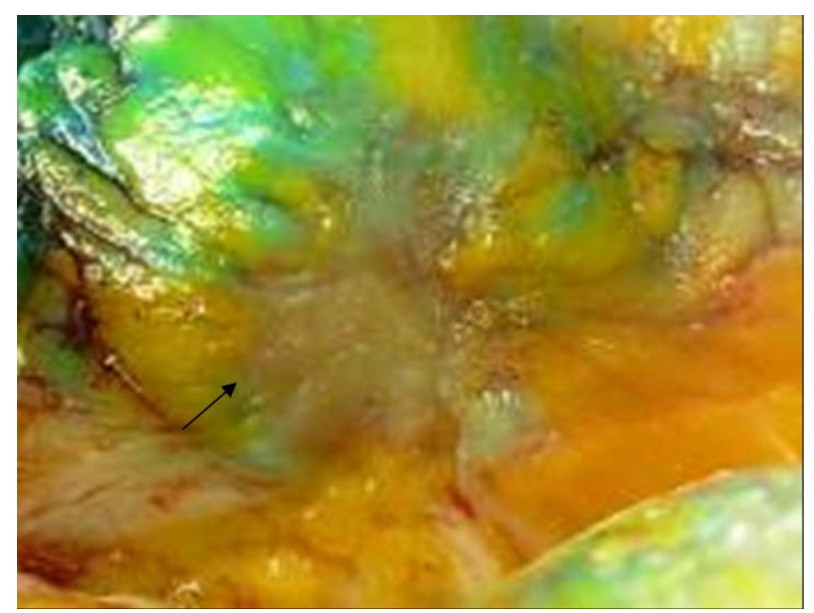

Figure 6. Breast specimen cut in parallel to the epidermis exposing a brownish-grey oval-shaped retroareolar nodule measuring $1.6 \times 0.7 \times 0.7 \mathrm{~cm}$ with ill-defined margins, radiating to the periphery.

Microscopy revealed invasive ductal carcinoma (Figure 7) with a histological malignancy grade of 2 in 3 and a high Nottingham prognostic index (5.72) associated with intraductal carcinoma and with compromised deep and lateral resection margins, in addition to invasion of breast vessels. Metastases were detected in three axillary lymph nodes. The pathological stage was pT 2 pN2a pMx.

Follow-up included eight sessions of chemotherapy and 30 sessions of radiotherapy. Treatment with tamoxifen was continued. One month after total thyroidectomy (TSH: $33.7 \mathrm{mIU} / \mathrm{mL}$, free T4: $0.43 \mathrm{ng} / \mathrm{dL}$ ), the patient was submitted to whole-body scanning with ${ }^{131}$ iodine, which showed thyroid remnants in the anterior neck region. Treatment was complemented with $3700 \mathrm{MBq}$ radioiodine. L-Thyroxine suppressive therapy was then initiated $(150 \mu \mathrm{g} /$ day) and six month later thyroglobulin was $0.3 \mathrm{mg} / \mathrm{mL}$ with no evidence of nodules or ganglia by neck ultrasound. One year later, the patient developed breast metastases to the liver and lungs and died within 3 months.

\section{Discussion}

This study reports a rare case of toxic papillary thyroid carcinoma concomitant to an invasive ductal carcinoma of the breast, with fatal outcome due to metastases and complications of the breast tumor. Whether this association is a coincidence or whether thyroid and breast tumorigenesis share common factors is the challenge of the analysis of this case.

In the present study, the diagnosis of toxic thyroid carcinoma was made by FNAB of the thyroid, confirmed by histopathological analysis, in a context of hyperthyroidism. Usually, aspiration biopsy of hot nodules, especially with the remaining of the gland suppressed, is not a routine procedure at our service. The personal history of cancer was considered a risk factor and if it would have not been taken into account, these findings would have been erroneously interpreted as Plummer's disease. In addition, the diagnosis of thyroid cancer by FNAB allowed better planning of the necessary surgical procedures.

Another atypical aspect of this case is the hormonal production by a thyroid carcinoma. Studies investigating the tumorigenesis of well-differentiated thyroid cancer have shown that follicular cells are less efficient in organifying iodine and processing thyroid hormones. Decreased radioiodine uptake due to reduced expression of the gene encoding the Na-I symporter (a glycoprotein involved in the transport of iodine into the thyroid cell) has been demonstrated. In contrast, toxic thyroid carcinomas comprise a highly differentiated subgroup whose molecular functions are preserved and that are able to process thyroid hormones [13], thus allowing the development of hyperthyroidism. In addition, somatic mutations in TSH receptor (TSH-R) genes have been detected not only in toxic adenoma [14] [15] but also in toxic thyroid carcinoma. These mutations lead to the constitutive activation of the intracellular cAMP cascade, inducing hormonogenesis in tumor cells [13] and thus explaining hyperthyroidism. 


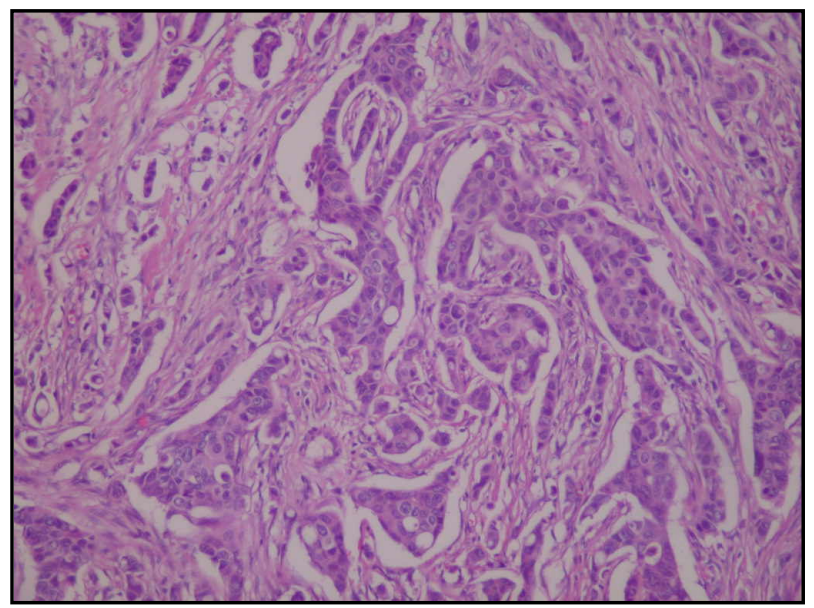

Figure 7. Invasive ductal carcinoma. Less than $10 \%$ of the neoplastic cells show a tubular arrangement. Note the moderate nuclear pleomorphism. Malignancy grade 2 of the invasive tumor (HE, 200×).

Controversies exist whether TSH-R mutations themselves induce cell proliferation or whether they are followed by other mutations in important oncogenes of intracellular signaling pathways such as MAPK, PI3K and Wnt [16] resulting in abnormal proliferation and tumorigenesis. These pathways are integrated into the cAMPPKA pathway and alterations in their cross-talk may result in cell proliferation and carcinogenesis.

Another unusual aspect of this case is the association between thyroid and breast cancer and its fatal outcome, raising the question whether the presence of thyroid disease aggravates or contributes to the unfavorable evolution of breast cancer. Literature data are not conclusive but some epidemiological studies have reported a higher prevalence of breast cancer among patients with thyroid diseases, especially hypothyroidism due to autoimmune disease [17]-[20], whereas others were unable to show such association [11]. Regarding to hyperthyroidism, the data are also conflicting. Vorherr [21] reported an increased survival of patients with hyperthyroidism and breast cancer. Saraiva et al. [22] suggested an association between breast cancer and subclinical hyperthyroidism, whereas no relationship between breast cancer and hyperthyroidism was observed in epidemiological studies involving large series of patients [23] [24].

The present case could be a rare coincidence of these two diseases that show a peak incidence at this age, with a questionable causal relationship between the two conditions. Claudine et al. [10], comparing the evolution of 19 cases of toxic papillary cancer and non-toxic papillary cancer, observed a lower 5-year survival rate in the former (56\% versus 94.5\%), suggesting higher aggressiveness of these tumors. In the present case, the metastases found in the liver and lungs were attributed to the breast cancer, indicating its aggressiveness.

The high T3 and T4 concentrations observed in the present case may have interfered with the behavior of the breast tumor, increasing its aggressiveness through cross-signaling in estrogen-signaling pathways or in other synergistic pathways, worsening its evolution. After total thyroidectomy, the patient went through successive periods of hyperthyroidism until receiving therapeutic complementation with radioiodine. Thyroxine therapy and TSH suppression were continued thereafter. These successive changes in T3 and T4 at the cellular level would be another aspect to be considered.

Nogueira and Brentani [25] demonstrated that triiodothyronine mimics the effects of estrogens in breast cancer cell lines. Similarly, Dinda et al. [26] showed the estrogen-like actions of thyroid hormones on the regulation of tumor suppressor proteins, p53 and retinoblastoma protein, in breast cancer cells.

\section{Conclusion}

In conclusion, this study describes the rare association between toxic thyroid cancer and breast cancer whose evolution suggests that elevated concentrations of T3 and T4 may have increased the severity of the latter. Taking the rarity of the simultaneous occurrence of these two diseases, future molecular studies may provide insights into the mechanisms of thyroid and breast tumorigenesis. 


\section{Disclosure Statement}

The authors have nothing to disclose and no competing financial interests exist.

\section{References}

[1] Molnar, G.D., Childs, D.S. and Woolner, L.B. (1958) Histologic Evidence of Malignancy in a Thyroid Gland Bearing a "Hot" Nodule. The Journal of Clinical Endocrinology \& Metabolism, 18, 1132-1134. http://dx.doi.org/10.1210/jcem-18-10-1132

[2] Bloise, W., Wajchenberg, B.L., Pieroni, R.R., Toledo, A.C., Mattar, E. and Cintra, A.B.U. (1963) Thyrotoxic Crisis and Electrolyte Disturbances in a Patient with Functioning Metastatic Carcinoma of the Thyroid: Chromatographic and Electrophoretic Studies. The Journal of Clinical Endocrinology \& Metabolism, 23, 1096. http://dx.doi.org/10.1210/jcem-23-11-1096

[3] McConnon, J.K., Von Westarp, C. and Mitchell, R.I. (1975) Follicular Carcinoma of the Thyroid with Functioning Metastasis and Clinical Hypothyroidism. CMA Journal, 22, 724-727.

[4] Cross, G.A., Suarez, H., Pitoia, F., Moncet, D., Vanegas, M., Bruno, O.D. and Niepomniszcze, H. (2008) Carcinoma and Graves Disease: Possible Implication of Cross-Signalling Mechanism. Arquivos Brasileiros de Endocrinologia \& Metabologia, 52-57, 1194-1200.

[5] Vini, L., Hyer, S., Brenda, P. and Harmer, C. (1989) Good Prognosis in Thyroid Cancer Found Incidentally at Surgery for Thyrotoxicosis. Thyroid Cancer, 75, 169-170.

[6] Shands, W.C. and Gatling, R.R. (1970) Cancer of the Thyroid: Review of 109 Cases. Annals of Surgery, 171, 735-743. http://dx.doi.org/10.1097/00000658-197005000-00013

[7] Gabriele, R., Letizia, C., Borghese, M., De Toma, G., Celi, M., Izzo, L. and Carvallaro, A. (2003) Thyroid Cancer in Patients with Hyperthyroidism. Hormone Research in Paediatrics, 60, 79-83. http://dx.doi.org/10.1159/000071875

[8] Terzioglu, T., Tezelman, S., Onaran, Y. and Tanakol, R. (1993) Concurrent Hyperthyroidism and Thyroid Carcinoma. British Journal of Surgery, 80, 1301-1302. http://dx.doi.org/10.1002/bjs.1800801027

[9] Russo, D., Tumino, S., Arturi, F., Vigneri, P., Grasso, G., Pontecorvi, A., Filetti, S. and Belfiore, A. (1997) Detection of an Activating Mutation of the Thyrotropin Receptor in a Case of an Autonomously Hyperfunctioning Thyroid Insular Carcinoma. The Journal of Clinical Endocrinology and Metabolism, 82, 735-738.

[10] Claudine, A.L.S., Gedeon, P., Rosler, H., Minder, C., Netzer, P. and Laissue, J.A. (2002) Survival Analysis of 19 Patients with Toxic Thyroid Carcinoma. The Journal of Clinical Endocrinology \& Metabolism, 87, 4122-4127. http://dx.doi.org/10.1210/jc.2001-011147

[11] Simon, M.S., Tang, M.T.C., Bernstein, L., Norman, S.A., Weiss, L., Burkman, R.T., Daling, J.R., Deapen, D., Folger, S.G., Malone, K., Marchbanks, P.A., McDonald, J.A., Strom, B.L., Wilson, H.G. and Spirtas, R. (2002) Do Thyroid Disorders Increase the Risk of Breast Cancer? Cancer Epidemiology, Biomarkers and Prevention, 11, 1574-1578.

[12] Sandeep, T.C., Strachan, M.W., Reynolds, R.M., Brewster, D.H., Scilo, G., Pukkala, E., et al. (2006) Second Primary Cancers in Thyroid Cancer Patients: A Multinational Record Linkage Study. The Journal of Clinical Endocrinology \& Metabolism, 91, 1819-1825. http://dx.doi.org/10.1210/jc.2005-2009

[13] Paul, S.J. and Sisson, J.C. (1990) Thyrotoxicosis Caused by Thyroid Cancer. Endocrinology and Metabolism Clinics of North America, 19, 593-612.

[14] Holzapfel, H.P., Bergner, B., Wonerow, P. and Paschke, R. (2002) Expression of Gàs Proteins and TSH Receptor Signaling in Hyperfunctioning Thyroid Nodules with TSH Receptor Mutations. European Journal of Endocrinology, 147, 109-116. http://dx.doi.org/10.1530/eje.0.1470109

[15] Derwahl, M., Manole, D., Sobke, A. and Broecker, M. (1998) Pathogenesis of Toxic Thyroid Adenomas and Nodules: Relevance of Activating Mutations in the TSH-Receptor and Gòs Gene, the Possible Role of Iodine Deficiency and Secondary and TSH-Independent Molecular Mechanisms. Experimental and Clinical Endocrinology \& Diabetes, 106, 56-59. http://dx.doi.org/10.1055/s-0029-1212048

[16] García-Jiménez, C. and Santisteban, P. (2007) TSH Signalling and Cancer. Arquivos Brasileiros de Endocrinologia \& Metabologia, 51, 654-671. http://dx.doi.org/10.1590/S0004-27302007000500003

[17] Dulger, H., Alici, S., Agun, E., Etlik, O., Sayarlioglu, M., Iogãn, E., Sayarliogla, H. and Sekeroglu, M.R. (2004) Antithyroid Antibody Levels in Patients with Breast Cancer. European Journal of General Medicine, 1, 11-14.

[18] Kuijpens, J.L.P., Nyklictek, I., Lowman, M.W.J., Weetman, T.A.P., Pop, V.J.M. and Coebergh, J.-W.W. (2005) Hypothyroidism Might Be Related to Breast Cancer in Post-Menopausal Women. Thyroid, 15, 1253-1259. http://dx.doi.org/10.1089/thy.2005.15.1253

[19] Turken, O., Narin, Y., Demirbas, S., Onde, M.E., Sayan, O., Kandemir, E.G., et al. (2003) Breast Cancer in Associa- 
tion with Thyroid Disorders. Breast Cancer Research, 5, R110-R113. http://dx.doi.org/10.1186/bcr609

[20] Gogas, J., KousKos, E., Tseleni-Balagouta, S., Markopoulos, C., Revenas, K., Gogas, G., et al. (2001) Autoimmune Thyroid Disease in Women with Breast Carcinoma. European Journal of Surgical Oncology, 27, 626-630. http://dx.doi.org/10.1053/ejso.2001.1204

[21] Vorherr, H. (1987) Thyroid Function in Benign and Malignant Breast Disease. European Journal of Cancer and Clinical Oncology, 23, 255-257. http://dx.doi.org/10.1016/0277-5379(87)90066-6

[22] Saraiva, P., Figueiredo, N., Padovani, C., Brentani, M. and Nogueira, C. (2005) Profile of Thyroid Hormones in Breast Cancer Patients. Brazilian Journal of Medical and Biological Research, 38, 761-765. http://dx.doi.org/10.1590/S0100-879X2005000500014

[23] Ron, E., Doody, M.M., Becker, D.V., Brill, A.B., Curtis, R.E., Goldman, M.B., Harris III, B.S.H., Hoffman, D.A., McConahey, W.M., Maxon, H.R., Preston-Martin, S., Warshaver, M.E., Wong, F.L. and Boice Jr., J.D. (1998) Cancer Mortality Following Treatment for Adult Hyperthyroidism. The Journal of the American Medical Association, 280, 347-355. http://dx.doi.org/10.1001/jama.280.4.347

[24] Hellevik, A.I., Asvold, B.O., Bjro, T., Romundstad, P.R., Nilsen, T.I. and Vatten, L.J. (2009) Thyroid Function and Cancer Risk: A Prospective Population Study. Cancer Epidemiology, Biomarkers \& Prevention, 18, 570-574. http://dx.doi.org/10.1158/1055-9965.EPI-08-0911

[25] Nogueira, C.R. and Brentani, M.M.J. (1996) Triiodothyronine Mimics the Effects of Estrogen in Breast Cancer Cell Lines. The Journal of Steroid Biochemistry and Molecular Biology, 59, 271-279. http://dx.doi.org/10.1016/S0960-0760(96)00117-3

[26] Dinda, S., Sanchez, A. and Mondgil, V. (2002) Estrogen-Like Effects of Thyroid Hormone on the Regulation of Tumor Suppressor Proteins, p 53 and Retinoblastoma, in Breast Cancer Cells. Oncogene, 21, 761-768. http://dx.doi.org/10.1038/sj.onc.1205136 
Scientific Research Publishing (SCIRP) is one of the largest Open Access journal publishers. It is currently publishing more than 200 open access, online, peer-reviewed journals covering a wide range of academic disciplines. SCIRP serves the worldwide academic communities and contributes to the progress and application of science with its publication.

Other selected journals from SCIRP are listed as below. Submit your manuscript to us via either submit@scirp.org or Online Submission Portal.
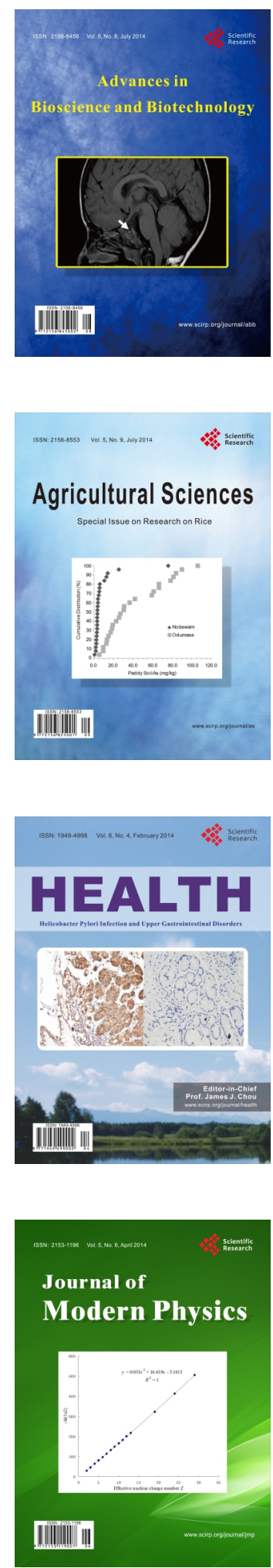
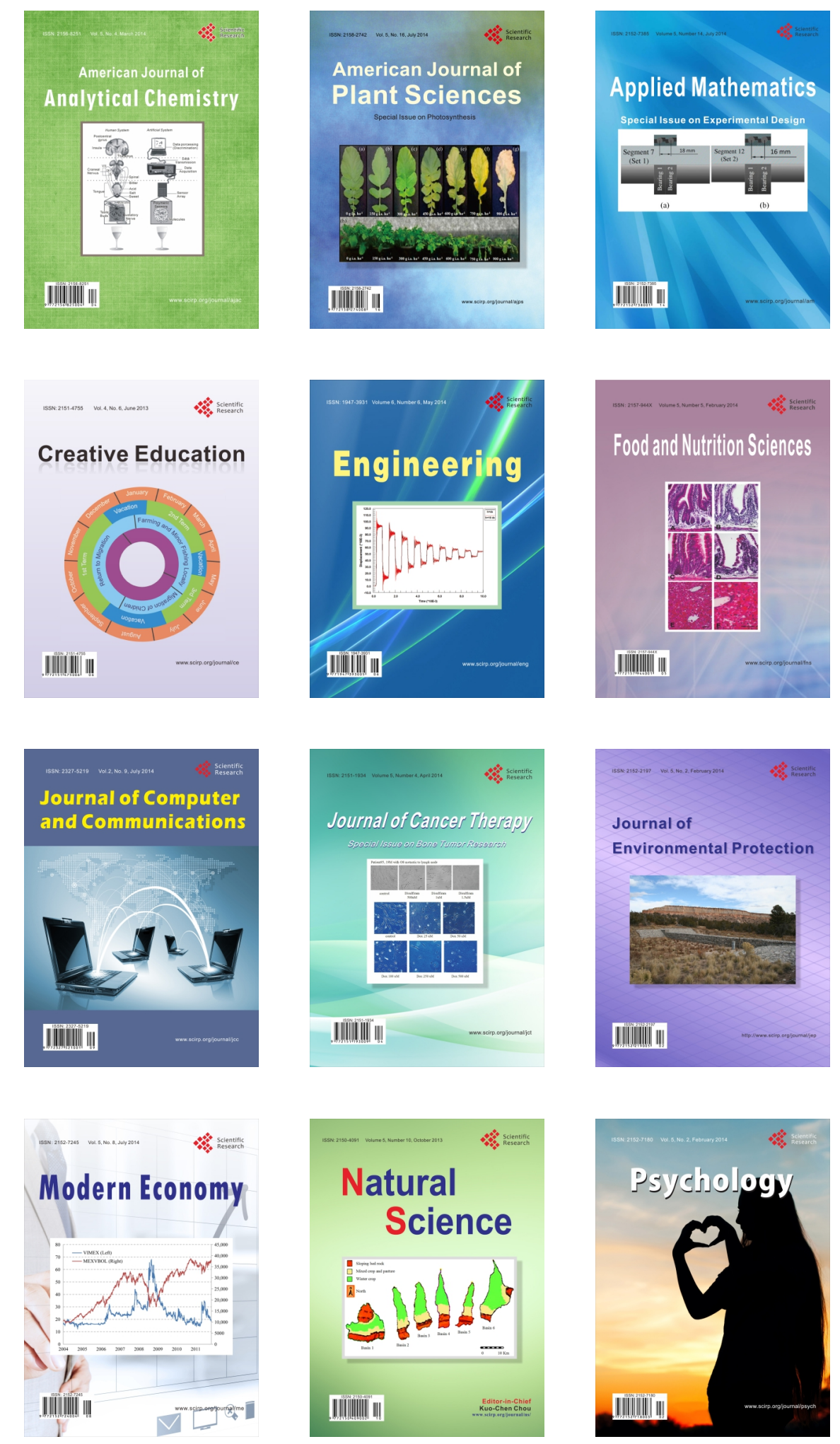